\title{
A COMPARATIVE ANALYSIS OF THE IMPACT OF AGRICULTURAL EXPORTS ON ECONOMIC GROWTH OF ECOWAS COUNTRIES
}

Richardson Kojo Edeme, Innocent A. Ifelunini, Nelson C. Nkalu*

\begin{abstract}
Towards the acceleration of the attainment of sustainable growth, most countries have focused on agricultural exports as a means of driving their economy. Developing countries of Africa are highly dependent on the agricultural sector and agricultural exports are a major determinant of economic growth of these countries. However, the impact of agricultural exports on economic growth of ECOWAS countries remains unclear. This study therefore evaluates the impact of agricultural exports on the economic growth of fifteen ECOWAS countries using panel data for the period 1980-2013. Variables employed are labour force participation rate, capital stock, agricultural exports, non-agricultural exports, inflation and economic growth. The results of the fixed-effect model show that agricultural exports have not impacted significantly on the economic growth of ECOWAS countries such as Côte d'Ivoire and Nigeria with respect to the Republic of Benin, which is the selected baseline. The study also analysed the country combined effect of the agricultural exports and found that it was significant but the rate of impact was weak. The study recommends, among others, that even though agricultural exports had a significant impact on economic growth, there is still a need for ECOWAS governments to improve their agricultural sector as its significance is more noticeable in some countries such as Côte $d^{\prime}$ Ivoire and Nigeria.
\end{abstract}

Keywords: agricultural exports, economic growth, panel data, random effect, fixed effect, ECOWAS JEL Classification: E6, F2

\section{Introduction}

The relationship between export and economic growth has raised global interest. Theoretically, it has been argued that a change in export rates could change output. Many consider export growth to be the determinant of economic growth in any economy, while some consider it to be the determinant of the production and employment growth which is reflected in the gross domestic product (GDP) growth [Corbo, Krueger \& Ossa, 1985; WTO, 2011]. Developing countries desire to achieve sustainable growth and development and exports are generally perceived as a motivating factor to achieving this. Meeting this challenge is crucial for the Economic Community of West African States (ECOWAS) to reduce food dependency and improve the current unfavourable terms of trade, by processing products and increasing value added. Agriculture plays a key role in ensuring

* Department of Economics, University of Nigeria, Nsukka, Nigeria (kojodynamics@yahoo.com; innocent.ifelunini@unn.edu.ng; nelson.nkalu@unn.edu.ng). 
food security for households, especially given the importance of on-farm consumption and the role of local markets in feeding urban populations.

The fifteen countries of ECOWAS possess varying capacities and potentials for the production of different crops. Nigeria, Ghana and Côte d'Ivoire are the three leading producers of agricultural products in the subregion and the main crops produced include: cassava, yam, cocoyam, sweet potato, plantain, bananas, onions, groundnuts, millet, cocoa, maize, rice, sorghum, beans and legumes. Rice, cassava, yam, millet, sorghum, sweet potatoes and maize constitute a major part of the diet in West Africa. Although over the years, crop production in West Africa has increased as a result of expansion of land under cultivation (horizontal expansion), the productivity of the land remains low across the subregion. Generally, agricultural productivity and yields are low in West Africa compared to other developing regions of the world. A comparison between West Africa and other regions shows that the index of cereal productivity for Cote d'Ivore in 2009 was $52 \%$, Latin America $65 \%$ and East Asia $66 \%$. With the exception of Ghana, all the countries in West Africa are still below the 1990 levels for cereal production in Latin America and East and South Asia.

In 2010, ECOWAS countries adopted the West African Common Industrial Policy with the key desire to increase the share of intra-regional trade from the currently around $12 \%$ of total trade to $40 \%$ by 2030 . The essence of this is to maintain a solid industrial structure that is globally competitive, environment-friendly and capable of significantly improving the living standards of the people [Aryeteey, 2012]. Adducing further reasons for the ECOWAS industrial policy, Collier and Gunning [1995] opined that the increasing interest in regional integration is often attributed to the disappointing progress of multilateral trade negotiations in the World Trade organization [WTO, 2011]. Undoubtedly, trading with regional neighbours is an important part of ECOWAS countries' overall trade expansion, poverty reduction and economic growth. However, each economic community in the world is generally characterized by the presence of one or two large economies and/or populations which dominate the respective communities. These large economies are envisaged as acting poles and drivers of growth in their respective regions. To overcome this, ECOWAS has aspired to increase trade interaction among its members through certain objectives, such as the elimination of custom duties and other charges of equal effect in respect of the exportation (and importation) of goods among member states; abolition of quantitative and administrative restrictions on trade among the member states; establishment of a common customs tariff and a common commercial policy towards third countries; and abolition of the obstacles inhibiting free movement of persons, goods, services and capital [Ezekwesili, 2011].

In the classic Heckscher-Ohlin model, a country's export composition is determined by its comparative advantage, which in turn depends on its factor endowments relative to that of its trading partners. Thus, the comparative advantage of a given country may vary depending on the trading partner's factor endowment. This would imply that the product composition of regional trade can be quite different from that of global trade, with potential repercussions of its impact on employment [Krugman, 1980]. The WTO Report [WTO, 2011] analysed the issue of product composition differences between regional and global trade empirically across broad categories of products (manufactures, parts and components, other) and arrived at the conclusion that while there appears to be no general global pattern, many regional trading areas reveal substantial differences in product composition between global and regional trade. On the theoretical side, Basu, Calamitis 
and Ghura [2000] argue that specialisation will occur according to regional rather than global comparative advantage as a consequence of regional integration. This can lead to divergence in terms of the economic structure among regional trading partners, with industrialisation only in the more advanced ones. Also Collier and Gunning [1995] note that preferential liberalisation within a region is likely to induce investment decisions that result in specialisation towards trade with regional partners (which may pose an obstacle to multilateral liberalisation). Both arguments are consistent with the idea of differences in product composition between global and regional trade, and add a dynamic perspective on the interaction between regional integration and comparative advantage. However, Utkulu [2004] argued that a traditional export model with explanatory variables such as export prices, variable home and foreign costs and productive capacity can be further extended by taking the effects of trade reform which consists of measures to reduce antiexport bias. In this regard, trade reform leads to the reduction of anti-export bias and a strong supply response, thus revealing that prices, relative prices and real exchange rates have no significant effect on export supply in the long run.

Studies such as Fosu [1990] and Deme [1995] examined the relationship between economic growth and exports using the error correction and co-integration models, focusing on eight Asian developing countries. Babatunde [2009] examined the impact of trade policy reform and regional integration on export performance of ECOWAS countries. The results revealed a dramatic decline in soil productivity, increasingly degraded natural resources and more and more conflicts over land use, particularly between farmers and herders, as pressure on land intensifies and good land becomes progressively saturated. On the other hand, disinvestment by governments, international institutions and development partners is also a cause for concern as little or no interest is shown in agriculture especially in a country like Nigeria where crude oil has been the major source of foreign exchange earnings. Meanwhile, agricultural exports fetch less on the international market while ECOWAS regional produce has been left to compete with cheap imports generated by the subsidies given to producers in developed countries. Towards diversification and to improve the economy, most countries have focused on agricultural exports as a means of stimulating growth. However, the impact of agricultural exports on economic growth of ECOWAS countries remains unclear. The objective of this study is to ascertain the level of impact that agricultural exports have had on the economic growth of ECOWAS countries using a panel analysis which spans from 1980 to 2013 and focuses on the fifteen countries. The study is apt because it will provide a platform for assessing the impact of agricultural exports on the economic growth of ECOWAS member countries, which will aid decision making and policy formulation towards developing a synergy in stimulating the growth process of the ECOWAS region.

\section{Conceptual issues}

\subsection{Agriculture as a means of economic growth}

The central role of agriculture in the growth process is a major contribution in the recent literature on structural transformation. The main thesis is whether agriculture continues to be an effective engine for growth especially in developing countries in light of the rapidly changing environment and the potential to import more food. Many staples in Africa are non-tradable, either due to local preferences or high transaction costs. In addition, in many 
countries, due to frequent shortages of foreign exchange for importing substitute cereals, food production has to keep up with domestic demand in order to maintain affordable food prices which are critical to overall growth. Even in Asian countries that have experienced a Green Revolution, increasing yields of staple crops remains critical for growth. Staple crops are still the largest agricultural subsector (slightly more than a third of agricultural output in China and India, and slightly more than half in Vietnam). Many of these countries have rice as the major staple, and given their size relative to world markets, they need to continue to produce most of their food domestically to secure low-cost food essential for growth. In addition, agriculture is often the lead export and foreign exchange earner since it is the sector with a strong comparative advantage in the early stages of development. Most African countries are relatively rich in natural resources, but poor in skilled labour, suggesting a comparative advantage for unprocessed primary products. This is reinforced by a weak business investment climate in terms of infrastructure and institutions that constrain private investment in the formal manufacturing and service industries. In some countries, a combination of natural resources, human capital endowments, and an improving business environment point to a comparative advantage in processed primary commodities, as a potential entry point for building a competitive manufacturing sector. Although globalization and new dynamic producers have increased competition in traditional agricultural exports, recent successes such as coffee in Vietnam and cocoa in Ghana suggest that agricultural exports can be major sources of growth. In Ghana, increased productivity in cocoa has been a major driver of its successful agricultural growth and poverty reduction since 1995. Even if there is general agreement on the importance of agriculture in economic growth in the early stages, it has been argued by Valdes [1993] that attaining rapid agricultural growth will be difficult in Africa because of its inherently unfavourable agro-ecological base, degraded soils, low population density, poorly functioning markets, and competition from the rest of the world. Yet, agriculture has been the most dynamic sector in Africa with growth rates of $3.7 \%$ annually, exceeding the growth in the non-agricultural sector over the 1993-2005 period. Even though it has been shown that over the long term, agriculture for most countries is likely to grow more slowly than non-agricultural sectors, globalization may endanger that through the provision of access to deeper markets with highly elastic demands for products such as fresh horticultural and organic produce and animal and fish products.

\subsection{Agriculture as a potent tool for poverty reduction}

It has been demonstrated by Daya, Ranoto and Letsoalo [2006] that a large and persistent gap exists between the share of agriculture in GDP and the labour force due to the slow movement of labour to other sectors such as industry. This is often hampered by lack of information, costs, skill gaps, aging, and family and social ties. The World Bank [1981] provides further evidence that growth in the rural economy is essential for reducing poverty in most developing countries. From a decomposition analysis, $81 \%$ of the reduction in rural poverty during the period 1993-2002 was ascribed to improved conditions in rural areas; migration accounted for only $19 \%$ of the reduction. It has also been argued that GDP growth generated in agriculture is particularly effective in benefiting the poor. This has been aptly demonstrated by Ghosh and Ostry [1994] who found that among 42 developing countries over 1981-2003, 1\% GDP growth originating 
in agriculture increased the expenditures of the five poorest deciles on average by $3.7 \%$, far more than the $0.9 \%$ induced by $1 \%$ GDP growth originating in the rest of the economy. Similarly, Kwan, Cotsomitis and Kwok [1999] found that an increase in overall GDP arising from agricultural labour productivity is on average 2.9 times more effective in raising the incomes of the poorest quintile in developing countries than an equivalent increase in GDP coming from non-agricultural labour productivity. Similar results hold for the agricultural growth-poverty linkages at the country level. In China, where land is relatively equally distributed, the reduction in poverty was almost four times higher from GDP growth originating in agriculture than from GDP growth originating in industry or services [Kweka \& Mboya, 2006; Daya, Ranoto \& Letsoalo, 2006]. Rapid agricultural development has also contributed substantially to the dramatic poverty reduction in Vietnam over the past 15 years and is likely to remain an important pathway out of poverty. However, rural poverty in some countries such as Bolivia, Peru, and Brazil has not declined despite rapid agricultural growth.

Some of the impact of agricultural productivity growth on poverty reduction can also be obtained directly through raising farm incomes, but much of it is indirect through employment and food prices. Studies of India for 1958-1994 by Grossman and Helpman [1991] where many of the rural poor are landless, report price and wage effects of food crop productivity to be more important in reducing rural poverty in the long run than direct effects on farm profits, which dominated in the short run. Although lower food prices reduce farm incomes, Fine and Yeo [1997] opined that the experience from the Green Revolution in Asia was that total factor productivity rose faster than the decline in food prices, leading to a win-win situation for poor producers and consumers. In addition to the urban poor and the rural landless, more than half of poor farm households are typically net food buyers who benefit from lower food prices. When a food crisis hits, a majority of poor smallholders are in fact hurt by rising prices, a somewhat counterintuitive outcome. With rising income, growth is increasingly driven by the rapidly expanding demand for livestock products and high-value crops, which are also more labour-intensive. The poverty impact of growth in the agricultural sector will thus depend increasingly on the poor connecting to these new growth processes, either as smallholders or as labourers on large farms. In spite of these gains, Wacziarg and Welch [2008] have argued that vertically integrated supply chains and supermarkets pose a huge challenge, although recent evidence from China suggests that small and poor farmers can take an active part in the rapidly expanding horticulture economy. A similar pro-poor pattern holds for India's dynamic dairy industry. In another strand, studies such as Mutairi [1993] and McCarthy [1997] have demonstrated that agricultural productivity growth also contributes to poverty reduction by stimulating rural non-farm growth, especially where infrastructure and the investment climate are already in place. For India and Indonesia, it has been estimated that growth in rural services contributed at least as much as growth in agriculture towards poverty reduction.

\subsection{Direction of trade and integration in ECOWAS countries}

West African countries are open small economies in which agricultural exports are by far the dominant source of foreign exchange earnings. Their degree of openness, as measured by their volume of trade, ranges from $29 \%$ in Guinea to $56 \%$ in Côte d'Ivoire, as compared to $15 \%$ for the United States. The export of primary commodities dominates economic 
activities in the West African region. The volume of exports is very concentrated on one or two commodities; the ratio is particularly high in Nigeria (95\%) because of the predominance of oil, making the trade situation very vulnerable. Indeed, agriculture suffers from the "Dutch disease" where, overall growth depends heavily on events on the oil market. For example, following the two major oil booms of 1973 and 1979-1980, the growth rate of non-oil exports, namely agricultural exports, fell dramatically. In addition, the trade balance fluctuates with the variations in oil prices; at relatively low oil prices in 1993-1995, the export growth was lower and so was the economic growth; in 1996 however, the growth improved as a result of an increase in oil prices. However, it has been eroded due to the current dip in crude oil prices. Côte d'Ivoire has a relatively diversified export basket and does not therefore depend heavily on any single cash crop. However, though coffee and cocoa still account for an important share of total trade, coffee production has decreased overtime and cocoa production has stagnated despite having very high ratios of tradable to total output, Burkina Faso and Senegal have the lowest ratio of exports to GDP when contrasted with Côte d'Ivoire, whose exports to GDP ratio is the highest. In particular, the share of agricultural output ranks the highest in Burkina Faso, whereas its agricultural exports fared poorly, leading to an overall low exports ratio. This points to the inability of Burkina Faso - and to some extent Senegal, Guinea and Nigeria - to convert potential exports in general and agricultural exports in particular, into actual exports. The case of Burkina Faso is due to its landlockedness, which could inflate the costs of transportation. This shows that the ability to purchase foreign goods, including food imports, with the country's own foreign exchange earnings is limited to the extent that such a gap can only be filled by food aid or by foreign debt.

\section{Literature review}

Several studies have been conducted on the impact of agricultural exports on economic growth. For instance, Melitz [2003] examined the causal relationship between economic growth and export growth using error correction models and time series data of eight Asian developing countries from 1960-1997. The results suggest that there was a bi-directional causality between export growth and economic growth in all the developing countries except Malaysia. In another study on the contribution of agriculture to economic growth in less developed countries, Santos-Paulino [2002] adopted two theoretical models in the analysis. The first model was based on agricultural production function, including both agricultural and non-agricultural exports as inputs. The second model was a dual economy model, i.e., agricultural and non-agricultural where each sector was subdivided into the export and non-export sectors. Fixed and random effects were estimated in each model using panel data of sixty-two less developed countries for the period 1974-1995. The study provided evidence from less developed countries that supported the theory of export-led growth. It also highlighted the role of agricultural exports in economic growth and therefore suggested a balance in export promotion policies. Aurangzeb's [2006] study of Pakistan was based on the analytical framework developed by Santos-Lopes and Dawson [2010]. The findings of the study showed that the export sector had significantly higher social marginal productivities. Hence, the study concluded that an export-oriented and outwardlooking approach was needed for high rates of economic growth. This outcome further spurred Ram [1987] to examine the linkage between agricultural exports and sustainable 
development. The study provided case studies of different countries that were involved in agricultural exports. It was Malik [2010] however, who provided an empirical analysis of the dynamic influence of economic reforms and liberalization of trade policy on the performance of agricultural exports. The effect of both domestic supply-side factors and external demand on the performance of agricultural exports was examined for Pakistan. The major finding was that export diversification and trade openness contributed more to agricultural export performance. This indicates that agricultural export performance is more elastic to change in domestic factors in relation to other non-oil exports.

Sanjuan-Lopez and Dawson [2010] estimated the contribution of agricultural exports to economic growth of 42 underdeveloped countries using the panel co-integration technique and the results indicated that there existed a long-run relationship between agricultural exports and economic growth, with agricultural exports having an elasticity of 0.07 and the non-agricultural export elasticity of GDP was 0.13 . In the same vein, Hausmann, Hwang and Rodrik [2007] examined the long-run elasticity of response of Uganda's predominantly agricultural primary commodity exports during the floating exchange rate regime in Uganda. The results suggest that Uganda's exports are positively and significantly correlated with relative prices and the levels of exchange rate, but negatively correlated with the terms of trade, capacity utilization, and exchange rate variability. A critical evaluation of individual subsectors indicated that the negative response to exchange rate variability is not universal for all products. Policy-wise, the results suggest that Uganda's export-led growth strategy must recognize the importance of these issues, but that it should also take full account of the differences in supply conditions and responses of particular subsectors.

In Nigeria, some studies have been conducted on the linkage between agricultural exports and economic growth. Notable in this strand are Ogunkoya, Bankole and Adewuyi [2006] in whose study five equations were estimated for aggregate output growth, and for output growths of each of the productive and service sectors in Nigeria. The results reported showed the following. (i) For the investment growth equation, the growth of the non-export sector as well as that of one-period lag of investment was positive and statistically significant. (ii) Non-export sector growth, terms of trade and average tariff were statistically significant in the export growth equation. The first two are positively signed while the growth of the average tariff had a negative sign, suggesting that a higher tariff brings about a lower export growth, confirming that a tax on imports is also a tax on exports. (iii) The investment policy reform appears to have influenced more the nonexport sector as the associated coefficient is positive and significant. Oyejide [2004] employed multiple regression analysis to examine the contribution of the agricultural sector on Nigeria's economic development and found that a positive relationship exists between gross domestic product, government expenditures on agriculture and foreign direct investment. Olajide et al. [2012] analysed the relationship between agricultural resources and economic growth in Nigeria. The OLS regression method was used to analyse the data. The results exhibited a positive cause-and-effect relationship between GDP and agricultural output.

From the empirical works, it can be observed that most studies have focused on the total exports as the only source of growth, but agriculture's share in total exports is generally substantial in underdeveloped economies. It is astonishing that empirical research on the contribution of agricultural exports to economic growth has been ignored 
to some extent in the literature despite its role in the development process having long been recognized. However, none of the studies have actually tried to address the impact of agricultural exports on economic growth of ECOWAS member countries using a panel data analysis; rather, most of them have focused on other developing countries. The knowledge gap is filled by this study.

\section{Materials and method}

The theoretical foundation of the study is the classical Solow growth model, which was further extended by Commer [2012]. The Solow model begins with a production function of the Cobb-Douglas type:

$$
Q=A K^{a} L^{b},
$$

where $A$ is multifactor productivity. If a $+\mathrm{b}<1$, it implies diminishing returns to a single factor and $\mathrm{a}+\mathrm{b}=1$ constant returns to scale. Solow noted that an increase in Q could occur from either an increase in $\mathrm{L}, \mathrm{K}$ or $\mathrm{Q} / \mathrm{L}$. However, due to diminishing returns to scale, this would imply a reduction in $\mathrm{Q} / \mathrm{L}$ or output per worker. Also an increase in the stock of capital would increase both output and $\mathrm{Q} / \mathrm{L}$ and an increase in $\mathrm{A}$ could also increase $\mathrm{Q} / \mathrm{L}$.

To actually evaluate what happens to $\mathrm{Q} / \mathrm{L}$ and hence, unless the employment ratio changes, Solow re-specified the Cobb-Douglas production function to a per capita function of the form:

$$
Q / L=A K^{a} L^{b-1}=A K^{a /} L^{1-b} .
$$

Since multiplying by $\mathrm{L}^{\mathrm{b}-1}$ is the same as dividing by $\mathrm{L}^{1-\mathrm{b}}$ and since $\mathrm{a}+\mathrm{b}=1$, $a=1-b$, the growth equation can be re-written as:

$$
Q=A K^{a} / L^{a}=A(K / L)^{a} .
$$

From the above analysis, the functional relationship between the dependent and independent variables based on data under consideration can be analogously expressed as:

$$
Y_{t}=A_{t} L_{t}^{\alpha} K t^{\beta} X_{A}^{\gamma} X_{N}{ }^{\delta} \pi_{t}^{\lambda} e^{\mu t},
$$

where $Y_{t}=$ aggregate production of the economy, $L_{t}=$ labour force participation, $K_{\mathrm{t}}=$ capital stock, $X_{A}=$ agricultural exports, $X_{N}=$ non-agricultural exports, $\pi_{\mathrm{t}}=$ inflation, and $t=$ time period; $\alpha, \beta, \gamma, \delta$ and $\lambda$ are elasticities of production with respect to labour, capital, agricultural exports, non-agricultural exports and inflation respectively.

Liberalizing the above function gives:

$$
\ln Y_{t}=\ln A_{t}+\alpha \ln L_{t}+\beta \ln K_{t}+\gamma \ln X_{A}+\delta \ln X_{N}+\lambda \ln \pi_{t}+\mu \mathrm{t},
$$

where all the coefficients are constant elasticity, $\mu$ tis the error term independent of all the other explanatory variables which indicate the influence of all the other factors. 
Due to the panel nature of the study, we introduce the cross sectional identities for the fifteen countries so that equation (5) becomes:

$$
\ln Y_{t i}=\ln A_{t i}+\alpha \ln L_{t i}+\beta \ln K_{t i}+\gamma \ln X_{A i}+\delta \ln X_{N i}+\lambda \ln \pi_{t i}+\mu t_{i}
$$

with $\mathrm{i}=$ countries $1-15$ and $\mathrm{t}=1980-2013$.

Equation (5) was adopted to estimate the impact of agricultural exports on economic growth for all the ECOWAS countries. To estimate the specific impact of agricultural exports on economic growth on each country, the dummy variable $\left(\mathrm{D}_{\mathrm{i}}\right)$ was introduced into equation (6) as shown below:

$$
Y_{i t}=\beta_{0}+\beta_{1} C_{i t}+\beta_{2} K_{i t}+\beta_{3} H_{i t}+\beta_{4} N_{i t}+\beta_{4} I_{i t}+\beta_{4} O_{i t}+\beta_{5} D_{i}+e_{i t}
$$

where $\mathrm{D}_{\mathrm{i}}$ is the dummy variable for all the 15 West African countries, thereby implying 14 dummies, considering the fact that one of them would become the base or omitted category. The essence of this is to avoid falling into the dummy trap.

Equation (6) above becomes the fixed-effects panel data estimation of the model for this study. This fixed-effects equation controls for all time-invariant differences among the countries, so the estimated coefficients of the fixed-effects models cannot be biased because of omitted time-invariant characteristics. That said, one of the side effects of the features of this fixed-effects equation above is that it cannot be used to investigate timeinvariant causes of the dependent variables. Technically, time-invariant characteristics of the countries are perfectly collinear with the country (or entity) dummies. Basically, fixed-effects models are mostly designed to study the causes of changes within an entity (country in this study). A time-invariant characteristic cannot cause such a change, because it is constant for each country.

In random effects, the variation across entities is assumed to be random and uncorrelated with the predictor or independent variables. The crucial distinction between fixed and random effects is whether the unobserved country effect embodies elements that are correlated with the regressors in the model. However, if it is assumed that differences across entities have some influence on the dependent variable, then a random-effects model is recommended. An advantage of the random effects over fixed effects is that one can include time-invariant variables, while in the fixed-effects model these variables are absorbed by the intercept. The random-effects model for equation 6 above can be specified as:

$$
Y_{i t}=\beta_{0}+\beta_{1} C_{i t}+\beta_{2} K_{i t}+\beta_{3} H_{i t}+\beta_{4} N_{i t}+\beta_{4} I_{i t}+\beta_{4} O_{i t}+\beta_{5} D_{i}+e_{i t}+\mu_{i t} .
$$

Equation (8) captures both the within-country and between-country errors unlike the fixed-effects model,which captures only the between-country error. In equation (8) above, the within-country error was captured with $\mu_{i t}$, while the between-country error was captured by $e_{i t}$. Data for this study were generated from the World Bank Database, structured according to the least-squares method for the fifteen countries. The STATA econometric software package was employed for the estimation. 


\subsection{Estimation procedure}

Data estimation follows different stages. First, the stationarity of the variables is conducted using the Fisher Unit root test. It is used due to its simple methodology and alternative hypothesis of heterogeneity. The test was conducted for all the variables under observation and wherein the variable was not stationary, it was made possible by differencing them. Although both the fixed-effects and random-effects models were conducted, the Hausman specification test was performed to ascertain which of the fixed-effects or random-effects models is more appropriate. Basically, it tests whether the unique errors $\left(\mu_{\mathrm{i}}\right)$ are correlated with the regressors. The Hausman test model can be represented as:

$$
H=\left(b_{1}-b_{0}\right)^{l}\left(\operatorname{Var}\left(b_{1}\right)-\operatorname{Var}\left(b_{1}\right) \times\left(b_{1}-b_{0}\right),\right.
$$

where $\chi$ denotes the Moore-Penrose pseudo-inverse, while the Vars are the estimates of the true covariance matrices. It is a three-step procedure so that when the [prob $>$ chi2] $<0.05$, then Ho is rejected, implying that the random-effects model is more appropriate; otherwise, the fixed-effects model is suitable.

\section{Presentation and discussion of results}

Table 1 | Results of unit root test

\begin{tabular}{|l|l|l|l|}
\hline \multicolumn{1}{|c|}{ Variable } & Difference & Time trend & Drift term \\
\hline Economic growth & First difference & Not included & Not included \\
\hline Agric exports & Third difference & Not included & Not included \\
\hline Inflation (CPI) & Third difference & Not included & Not included \\
\hline Labour force & Third difference & Not included & Not included \\
\hline Capital stock & First difference & Not included & Not included \\
\hline Non-agric exports & Third difference & Not included & Not included \\
\hline
\end{tabular}

Source: Authors' own calculation

From the results of the unit root test in Table 1, it can be observed that only economic growth and capital stock were stationary at the first difference, without the time trend and drift term, while agricultural exports, inflation rate, labour force participation rate and non-agricultural exports were stationary after the third difference with the time trend and drift term not included. Although the results of both the random-effects model and fixed-effects model are presented for comparison purposes, the interpretation of empirical results is based on the fixed-effects model because of the outcome of the Hausman specification test, which points to the rejection of the null hypothesis, an indication that the fixed-effects model is more appropriate. 
Table 2 | Results of the Hausman specification test

\begin{tabular}{|c|c|}
\hline chi2(5) $=(\mathbf{b}-\mathbf{B})^{c}\left[\left(\mathbf{V}_{-} \mathbf{b}-\mathbf{V}_{-} B\right)^{\wedge}(-1)\right](b-B)$ & Prob $>$ chi2 \\
\hline 36.98 & 0.0000 \\
\hline
\end{tabular}

Source: Authors' own calculation

The results of the independent effect in the ECOWAS countries with the dummy effect variable is presented in Table 3.

Table 3 | Panel results of the impact of agricultural exports on economic growth for each of the ECOWAS countries

\begin{tabular}{|c|c|c|c|c|c|}
\hline \multirow{3}{*}{\multicolumn{2}{|c|}{ Variable }} & \multicolumn{4}{|c|}{ All explanatory variables included } \\
\hline & & \multicolumn{2}{|c|}{ Fixed effects } & \multicolumn{2}{|c|}{ Random effects } \\
\hline & & Coefficient & $P>|z|$ & Coefficient & $P>|z|$ \\
\hline Lab & participation rate & .278 & 0.413 & .364 & 0.200 \\
\hline Cap & & .380 & $0.008^{*}$ & .337 & $0.014^{*}$ \\
\hline Agr & ports & .021 & 0.588 & .096 & $0.001^{*}$ \\
\hline Bur & & -.056 & 0.810 & -.049 & 0.833 \\
\hline Cap & & -.404 & 0.118 & -.482 & 0.062 \\
\hline Côt & & -.627 & 0.245 & -1.113 & $0.024^{*}$ \\
\hline Gan & & .418 & 0.151 & .100 & 0.685 \\
\hline Gha & & -.164 & 0.656 & -.648 & 0.059 \\
\hline Gui & & -.012 & 0.964 & -.278 & 0.262 \\
\hline Gui & & -.137 & 0.654 & -.204 & 0.479 \\
\hline Libe & & 1.041 & $0.004^{*}$ & .986 & $0.005^{*}$ \\
\hline Mal & & .173 & 0.522 & .265 & 0.327 \\
\hline Nig & & -.215 & 0.406 & -.334 & 0.187 \\
\hline Nig & & .435 & 0.229 & .057 & $0.021^{*}$ \\
\hline Sen & & -.392 & 0.099 & -.539 & $0.020^{*}$ \\
\hline Sier & & .014 & 0.976 & -.425 & 0.313 \\
\hline Tog & & .031 & 0.899 & -.125 & 0.618 \\
\hline Non & ral exports & -.007 & 0.844 & -.014 & 0.416 \\
\hline Infla & & .008 & 0.081 & .001 & $0.006^{*}$ \\
\hline Con & & -.501 & 0.769 & -.182 & 0.888 \\
\hline & $\begin{array}{l}\text { Within } \\
\text { Between } \\
\text { Overall }\end{array}$ & $\begin{array}{l}0.5980 \\
0.4115 \\
0.5071\end{array}$ & & $\begin{array}{l}0.5587 \\
0.5551 \\
0.4343\end{array}$ & \\
\hline Pro & i Square & 0.004 & & 0.000 & \\
\hline
\end{tabular}

Source: Authors' own calculation; *indicates significance at $5 \%$ significance level 
The results indicate that the overall probability chi square for the fixed effects is significant. The results equally show that apart from non-agricultural exports, every other variable in the model had a positive relationship with economic growth of the ECOWAS region. The implication of this is that when labour force participation rate, capital stock, agricultural exports and inflation rate are increasing, economic growth also increases. On the contrary, an increase in non-agricultural exports will lead to a decrease in economic growth. The results here are somewhat expected. This is based on the economic theory which posited that when there is mild inflation, output increases. Similarly, the more people participate in production (especially when the input of labour has not reached its diminishing returns), the greater the output of labour, which leads to increased economic growth. Also, the more the stock of capital for production increases, economic growth is equally expected to increase. This is because production is done especially through stored-up capital and borrowings (especially stored-up capital). More so, agricultural exports were equally expected to have a positive relationship considering that most countries in Africa are primary product producers and an increase in the production of these products could lead to a better availability of raw materials for industrial output (especially when a country in the region produces and another buys). However, the negative relationship between non-agricultural exports and economic growth could be the effect of excessive drive for exportation of goods of which the citizens do not even have enough for their own consumption as it will end up increasing the importation of such commodities.

Considering the country-specific effect, the results indicate that agricultural exports had a positive relationship with economic growth with respect to the base category, except Burkina Faso, Cape Verde, Côte d'Ivoire, Ghana, Guinea, Guinea-Bissau, Niger and Senegal, while it had a negative effect on economic growth of Ghana, Burkina Faso and Senegal, among others, although the impact of agricultural exports on economic growth was high in some countries, it was moderate in others and in some countries it was weak. Overall, although a positive relationship exists between agricultural exports and economic growth in this region, it has not contributed to the growth process in ECOWAS member counties. This could be attributable to varying agricultural reforms introduced

\section{Table 4 | Regression results of the collective impact of agricultural exports on economic growth} for all ECOWAS countries

\begin{tabular}{|l|c|c|}
\hline \multicolumn{1}{|c|}{ Variable } & \multicolumn{2}{c|}{ All explanatory variables included } \\
\hline & Coefficient & P >|z| \\
\hline Labour force participation rate & .003 & $0.009^{*}$ \\
\hline Capital stock & -.012 & 0.911 \\
\hline Agricultural exports & .005 & $0.039^{\star}$ \\
\hline Non-agricultural exports & -1.202 & 0.250 \\
\hline Inflation & -.010 & 0.065 \\
\hline Constant & 92.434 & $0.007^{*}$ \\
\hline$R^{2}$ & & \\
\hline Probability Chi Square & 0.445 & \\
\hline
\end{tabular}

Source: Authors' own calculation; *indicates significance at 5\% significance level 
by these countries. Also the underdeveloped nature of the region may have contributed to the decreasing effect of some variables especially labour force participation rate and non-agricultural exports in contributing to agricultural export and thus insignificant. The results conform to the findings of Fosu [1990] who posited that agricultural exports have not contributed significantly to economic growth of less developed countries.

The collective impact of agricultural exports on economic growth for all the ECOWAS member countries was also investigated and the results are presented in Table 4.

The results show that the $\mathrm{R}^{2}$ is 0.445 . This means that the explanatory variables explain the variations in the economic growth of the ECOWAS region by about $45 \%$. The implication of this result is that the explanatory variables were not the major determinants of economic growth in the region. The results further show that the probability chi square is 0.005 , an indication that the overall regression was significant since the probability chi square of 0.005 was less than the 0.05 maximum standard significance levels. Specifically, the results show that capital stock, non-agricultural exports and inflation rate had a negative relationship with economic growth. This implies that a unit increase in either of capital stock, non-agricultural exports and inflation rate decreases economic growth. The negative effect exhibited by capital stock could be the effect of poor management of capital or misplacement of priority in terms of investment of capital where there are already full employment of resources and diminishing returns. Similarly, the negative relationship between non-agricultural exports could be the effect of monotony of products in many developing countries. For instance, the overdependence on oil, on which many countries in the ECOWAS region depend, especially Nigeria, has helped in making them a one-product economy and the exportation of this product does not reflect economic advancement as the advancement is mostly championed by happenings in one sector of the economy, which makes development impossible. Besides, the increase in non-agricultural exports may be championed by a sector which discourages investment in other sectors and even when total non-agricultural exports are increasing because of the discouragement that the driving sector has on other sectors, it will make the contribution of non-agricultural exports to economic growth negative. Also the contribution of the explanatory variables to the economic growth of the region was weak except non-agricultural exports, where a unit increase brought about a reduction in economic growth by $1.20 \%$ whereas a unit increase in agricultural exports, inflation, labour force participation rate and capital stock led to increases of $0.005,0.010,0.003$ and 0.012 in economic growth respectively.

\section{Conclusions}

This study is motivated by the increasing concern about whether agricultural exports have been significant in the economic growth of the ECOWAS region. The results of the panel data show that the significance of the effect of agricultural exports has varied across countries. Furthermore, the results for the first model equally show that labour force participation rate, capital stock, agricultural exports and inflation rate have a positive relationship with economic growth of the ECOWAS region, whereas non-agricultural exports have a negative effect on economic growth of the region. However, the magnitude of the relationship between the explanatory variables and economic growth as evidenced by their coefficients was weak. This shows that they have little effect on the economic 
growth of ECOWAS. On the basis of the second model, only agricultural exports and labour force participation rate had a significant collective impact on the economic growth of the ECOWAS region. The other explanatory variables of capital stock, nonagricultural exports and inflation had an insignificant impact on the economic growth of the ECOWAS region. Similarly, only labour force participation rate and agricultural exports have a positive relationship with economic growth of ECOWAS, while capital stock, non-agricultural exports and inflation rate all have negative relationships with economic growth of the region. The results of our analysis further show that agricultural exports exerted an insignificant individual impact on the economic growth of ECOWAS countries, even though concerning country-specific effect, the agricultural exports had a significant impact on economic growth in Liberia only. Among the combined effects, agricultural exports and labour force participation rate had a significant positive effect on economic growth while capital stock, non-agricultural exports and inflation were insignificant and all three having a negative impact.

\section{Policy recommendations}

A major policy implication of the above findings is that agricultural exports have a positive impact on the economic growth of the ECOWAS region for the combined effect - and the country-specific effect for some countries - and thus, that agriculture should not be neglected by the region because it has the potential to engender economic growth. It has therefore become necessary to advise the respective governments in these countries to work towards commercialising and mechanising the agricultural sector to improve its contribution to their respective economies and to the ECOWAS region in general, as this might have been the reason for the weak (though significant) impact of agricultural exports on economic growth. ECOWAS governments are advised to intensify their investment in agricultural exports as they increase economic growth. Also, the insignificant contribution of labour force participation rate in the first model implies that increasing labour as a factor of production adds positively to economic growth; hence, the ECOWAS region is advised to check the quality of its labour intake. This could be done by following due processes in the employment of workers and standardising the educational sector. More so, the results of the analysis of the second model showed that capital stock had an insignificant negative impact on economic growth of the ECOWAS region. This implies that capital formation in the ECOWAS region is still very low and this calls for concerns and the various ECOWAS governments are advised to create avenues that will increase capital stock. Also, they should equally ensure that resources are properly and efficiently utilized to achieve the maximum output. The insignificant contribution of non-agricultural exports to economic growth of ECOWAS explains further the underdeveloped nature of the region in terms of infrastructure and access to raw materials, poor investment climate and lack of incentives to manufacturing and exportation, among others. On this, the ECOWAS governments are advised to make the region's business environment attractive through the provision of infrastructures, especially, a good road network, improve the transportation system, improve power generation, distribution and consumption, reduce the costs of doing business in the region, encourage manufacturers - especially those that export - with incentives, ensure that raw materials are easily sourced, and assist manufacturers with credit where necessary. 


\section{References}

ARYETEEY, E., 2012. Regional integration in West Africa [OECD Development Centre Working Paper No. 170]. OECD Publishing, Paris. DOI: http://dx.doi.org/10.1787/751603543122.

AURANGZEB, R., 2006. Exports, productivity and economic growth in Pakistan: a time series analysis. The Lahore Journal of Economics, 11(1), 1-18. ISSN 1811-5438.

BABATUNDE, M. A., 2009. Can trade liberalization stimulate export performance in Sub-Saharan Africa? Journal of International and Global Economic Studies, 2(1), 68-92. ISSN 1940-655X.

BASU, A., CALAMITSIS, E. A. \& GHURA, D., 2000. Promoting growth in Sub-Saharan Africa: learning what works. Washington D.C.: International Monetary Fund. ISBN 1-55775-966-9.

COLLIER, P. \& GUNNING, J., W., 1995. Trade policy and regional integration: implications for relations between Europe and Africa. The World Economy, 18(3), 387-410.

DOI: http://dx.doi.org/10.1111/j.1467-9701.1995.tb00221.x.

CORBO, V., KRUEGER, A. O. \& OSSA, F., 1985. Export-oriented development strategies: the success of five newly industrialized countries. London: Westview Press.

DAYA, Y., RANOTO, T. R. \& LETSOALO, M. A., 2006. Intra-Africa agricultural trade: a South African perspective. Acta Commercii 6(1), 99-113. ISSN 1684-1999.

DEME, M., 1995. The impact of ECOWAS on intraregional trade flows: an empirical investigation. The Review of Black Political Economy, 23(3), 113-29.

DOI: http://dx.doi.org/10.1007/BF02689995.

EZEKWESILI, C. E., 2011. Can the monetary integration of ECOWAS improve intra-regional trade? [online]. [accessed July 25, 2015]. CMC Senior Theses, Paper 279. Available at: http://scholarship.claremont.edu/cmc_theses/279/

FINE, J. \& YEO, S., 1997. Regional integration in Sub-Saharan Africa: dead end or a fresh start? In Collier, P. \& Oyejide, A. (eds.). Regional Integration and Trade Liberalization in Sub-Saharan Africa, Vol. 1. London: Macmillan, 428-474. ISBN 978-0-333-66104-8.

FOSU, A. K., 1990. Exports and economic growth: the African case. World Development, 18(6), 831-835. ISSN 0305-750X. DOI: http://dx.doi.org/10.1016/0305-750X(90)90005-I.

GHOSH, A. R. \& OSTRY, J. D., 1994. Export instability and external balance in developing countries. Staff Papers - International Monetary Fund, 41(2), 214-235.

DOI: http://dx.doi.org/10.2307/3867507.

GROSSMAN, G. \& HELPMAN, E., 1991. Innovation and growth in the global economy. Cambridge: MIT Press. ISBN 9780262071369.

HAUSMANN, R., HWANG, J. \& RODRIK, D., 2007. What you export matters. Journal of Economic Growth, 12(1), 1-25. DOI: http://dx.doi.org/10.1007/s10887-006-9009-4.

KRUGMAN, P., 1980. Scale economies, product differentiation, and the pattern of trade. American Economic Review, 70 (5), 950-959. DOI: http://dx.doi.org/10.2307/1805774.

KWAN , A. C. C., COTSOMITIS, J. A. \& KWOK, B. K. C, 1999. Export economic growth and structural invariances: evidence from some Asian NICS. Applied Economics, 31 (4), 493-498. DOI: http://dx.doi.org/10.1080/000368499324200.

KWEKA, J. \& MBOYA, F., 2006. Regional integration and poverty: the case of Tanzania. In te Velde, D. W. (ed.). Regional integration and poverty. London: Routledge, 165-226. ISBN 978-0754646525.

MALIK, N., 2010. Pakistan agricultural export performance in the light of trade liberalization and economic reforms. World Journal of Agricultural Sciences, 6(1), 29-38. ISSN 1817-3047. 
MCCARTHY, E., 1997. Regional integration in Sub-Saharan Africa: past, present and future. In Collier, P. \& Oyejide, A. (eds.). Regional Integration and Trade Liberalization in Sub-Saharan Africa, Vol. 1. London: Macmillan, 428-474. ISBN 978-0-333-66104-8.

MELITZ, M., 2003. The impact of trade on intra-industry reallocations and aggregate industry productivity. Econometrica, 71(6), 1695-1725.

DOI: http://dx.doi.org/10.1111/1468-0262.00467.

MUTAIRI, N. A., 1993. Exports and Pakistan's economic development. Pakistan Economic and Social Review, 31(2), 134-146. ISSN 1011002X.

OGUNKOYA, E. O., BANKOLE, D. \& ADEWUYI, P., 2006. An empirical evaluation of trade potential in the economic community of West African states [Research Paper no. 84]. African Economic Research Consortium. ISBN 9966-900-90-X.

OLAJIDE, O. T., AKINLABI, B. H. \& TIJANI, A. A., 2012. Agriculture resource and economic growth in Nigeria. European Scientific Journal, 8(22), 103-115. ISSN 1857-7881.

OYEJIDE, T. A., 2004. African trade policy in the context of national development strategies [online]. [accessed July 25, 2015]. ECA Conference of African Ministers of Finance, Planning and Economic Development. May 22, Kampala, Uganda. Available at: http://www.uneca.org/cfm/2004/052204_African_trade_policy.htm

RAM, R., 1987. Exports and economic growth in developing countries: evidence from timeseries and cross-section data. Economic Development and Cultural Change, 36(1), 51-72. DOI: http://dx.doi.org/10.1086/451636.

SANJUAN-LOPEZ, A. I. \& DAWSON, P. J., 2010. Agricultural exports and economic growth in developing countries: a panel co-integration approach. Journal of Agricultural Economics, 61(3), 565-583. DOI: http://dx.doi.org/10.1111/j.1477-9552.2010.00257.x.

SANTOS-PAULINO, A. U., 2002. Trade liberalization and export performance in selected developing countries. The Journal of Development Studies, 39(1), 140-164. DOI: http://dx.doi.org/10.1080/00220380412331322701.

UTKULU, U., SEYMEN, D. \& ARI, A., 2004. Export supply and trade reform: the Turkish evidence [Conference paper no. 330600144]. International Conference on Policy Modelling, Paris, June 30 - July 2.

VALDES, A., 1993. The macroeconomic environment necessary for agricultural trade and price policy reforms. Food Policy, 18(4), 272-283.

DOI: http://dx.doi.org/10.1016/0306-9192(93)90045-D.

WACZIARG, R. \& WELCH, K. H., 2008. Trade liberalization and growth: new evidence. World Bank Economic Review, 20(2), 187-231. DOI: http://dx.doi.org/10.1093/wber/lhn007.

WORLD BANK, 1981. Accelerated development in sub-Saharan Africa: an agenda for action [online]. [accessed December 12, 2015]. Washington, D.C.: The World Bank. Available at: http://documents.worldbank.org/curated/en/702471468768312009/Accelerateddevelopment-in-sub-Saharan-Africa-an-agenda-for-action

WTO, 2011. World Trade Report: The WTO and preferential trade agreements: from co-existence to coherence. Geneva. ISSN 1474-7456. 